$\boldsymbol{D}_{\text {Wuhanista ja Sinisestä projektista }}$ Georgialaiseen: Virukset kauhun aiheuttajana dystopiafiktiossa

Jyrki Korpua 
uosi 2020 tullaan muistamaan niin sanotun uuden SARSV COV-2 -koronaviruksen leviämisestä ja viruksen aiheuttamasta maailmanlaajuisesta COVID-19 -pandemiasta. ${ }^{1}$ Vallitseva maailmantilanne on tuonut ajoittain mieleen dystopiafiktion esiin nostamat uhat, joissa tartuntataudit aiheuttavat massatuhoa, globaalin katastrofin tai jopa maailmanlopun. Jo aiemmin reaalimaailman todelliset ongelmat, kuten huoli ilmastonmuutoksesta tai populistisen politiikan nousu, ovat aiheuttaneet länsimaissa dystopiabuumin (ks. Isomaa \& Lahtinen 2017). Nyt maailmankatsomustamme mullistanut COVID-19 -pandemia on entisestään nostanut esiin dystopiafiktion teemoja myös reaalimaailmassamme. Tämä artikkeli ei kuitenkaan käsittele reaalimaailman ongelmia, vaan keskittyy fiktiivisen maailman sisäisiin tautikriiseihin; viruksiin pandemian syinä ja kauhun aiheuttajina dystooppisessa kauhu- ja tieteisfiktiossa. ${ }^{2}$ Pääväittämäni on, että dystopiafiktiossa kauhua synnyttävät virukset toimivat varoituksena myös reaalimaailmassa mahdollisesta kehityksestä. Erityisesti tämä huoli nousee esiin kirjallisuudessa, jossa ihmisillä on aktiivinen rooli viruksen levittäjänä - siis esimerkiksi silloin, kun virusta käytetään bioaseena.

Artikkelini tutkii viruksia kauhun ja fiktiivisen maailman tartuntatautien aiheuttajana klassikoiksi luettavissa kauhukertomuksissa, Stephen Kingin Tukikohdassa (The Stand, 1978; tästä eteenpäin S) ja Dean R. Koontzin Pimeyden silmät -romaanissa (The Eyes of Darkness, 1981, uudistettu painos 1989, alun perin julkaistu nimellä Leigh Nicholls; tästä eteenpäin ED), sekä Emily St. John Mandelin tuoreemmassa tieteisromaanissa Station Eleven (2014; tästä eteenpäin SE). Vaikka kaksi teoksista edustaa kauhufiktiota ja yksi tieteisfiktiota, voidaan niitä kaikkia pitää myös dystopiafiktiona. Ne ovat lisäksi kaikki suuren suosion saavuttaneita teoksia, ${ }^{3}$ jotka ovat saaneet uuden merkittävän nosteen luku- ja myyntitilastoissa juuri vallitsevan COVID-19 -pandemian aikana. Niiden aiheet on nähty nyt piinaavan ajankohtaisina; Pimeyden silmät nousi jopa Amazonin myyntitilaston kärkeen maaliskuussa 2020 (Flood 2020; ks. myös Martin 2020; Kelly 2020). Artikkelissani selvitän sekä laaja-alaisemmin virusten lajiteknistä merkitystä että yksityiskohtaisemmin sitä, millaisia kauhun aiheuttajia virukset ovat valituissa teoksissa. Tarkastelen sitä, millainen on teosten virusten alkuperä, miten virus leviää ja vaikuttaa teoksissa sekä miten teosten henkilöhahmot reagoivat viruksiin.

Populaarikirjallisuuden näkökulmasta uhat ovat kiehtovia. Dystopiafiktio on ollut viime vuosien aikana erityisen suosittua sekä kirjallisuudessa, televisiossa, elokuvissa että peleissä, kuten televisio- ja elokuvasarjat Handmaid's Tale (2017-) ja Hunger Games (2012-15) tai pelit kuten Fallout (1997-) ja Resident Evil (1996-) osoittavat. Kirjallisuuden puolella George Orwellin klassikko Vuonna 1984 (Nineteen Eighty-Four, 1949) nousi Donald Trumpin virkaannousun jälkeen vuonna 2017 poikkeuksellisiin myyntilukuihin, mikä sai kustantajan tekemään uuden suuren painoksen (Freytas-Tamura 2017). Margaret Atwoodin vuonna 
1985 julkaistu Orjattaresi (The Handmaid's Tale) kohosi sekin vuonna 2017 bestselleriksi ja vuoden luetuimmaksi kirjaksi (Amazon 2017). Dystopiafiktion alalajit, apokalypsit, postapokalypsit ja niin sanottu ilmastofiktio sekä katastrofifiktio, joissa keskeisenä aiheena ovat suuret mullistukset ja uhat, ovat nousseet erittäin suosituiksi lukijoiden keskuudessa. (Isomaa \& Lahtinen 2017, 3; Isomaa, Korpua \& Teittinen 2020, ix-x.) Koronaviruspandemia on palauttanut kiinnostuksen myös globaaleja tartuntatautiuhkia käsittelevään kirjallisuuteen, kuten kohdeteosten kasvanut suosio osoittaa.

Taudit ovat vaikuttaneet maailmankirjallisuuteen monin tavoin. Tämä ei ole vain nykypäivän ilmiö, sillä ihmiskunta on aina ollut tautien riivaama, mikä näkyy myös kirjallisuudessamme. Raamatussa on kymmeniä viittauksia erilaisiin sairauksiin, kulkutauteihin ja Jumalan lähettämiin vitsauksiin, joilla syntisiä rangaistaan (ks. Harrison 1953). Apokalyptinen vitsauskuvasto, jopa "tuhon erotisointi", on ollut kirjallisuuden keskiössä vuosituhansien ajan (ks. Gomel 2000). Vitsauksista juuri tauteja on kuvattu tarkasti jo hyvin varhain. Raamatusta löytyy 1. Samuelin kirjan 6. luvusta ensimmäinen tunnettu viittaus bakteerin aiheuttamaan keuhkoruttoon (Blondheim 1955). Kulkutaudit ovat mielenkiintoisia kauhun luojia, jotka paitsi pelottavat ja järkyttävät, myös yhtä lailla kiehtovat. Kirjallisuushistoriassa kulkutaudit nousevat esiin viimeistään Boccaccion Decameronessa (1353), jossa kokonaisuus rakentuu kehyskertomuksen mukaan Fiesoleen "mustaa surmaa" paenneiden nuorten kertomista tarinoista. Daniel Defoen Ruttovuosi (A Journal of the Plague Year, 1722) vuorostaan käsittelee vuoden 1665 Lontoon suurta ruttoepidemiaa poikkeuksellisella tarkkuudella. Kulkutauti aiheena on ollut suosittu myöhemminkin, nousten erityisellä tavalla esiin Albert Camus'n Rutossa (La Peste, 1947), joka kertoo algerialaisen Oranin kaupungin asukkaiden taistelusta tuhoisaa epidemiaa vastaan. Rutto on myös massaepidemian leviämisen sosiaalinen kuvaus ja sopii mainiosti 2020-luvun kontekstiin, vaikkakin alkuperäisteoksen allegoriset tulkinnat fasismista ovat nykylukijalle usein tuntemattomia.

Kohdeteokset kuvaavat vaarallisia virusepidemioita; Tukikohdan ja Station Elevenin tapauksissa pandemioita, jotka vaarantavat olemassa olevan yhteiskunnan ja koko ihmiskunnan tulevaisuuden. Tukikohdassa armeijan kehittelemä koodinimi "Sininen projekti" karkaa luojiltaan ja tuhoaa lähes koko ihmispopulaation. Pimeyden silmissä päätarinan taustalla on murhaavan tehokas bioase, joka vuoden 1989 uudistetussa versiossa, jota tässä artikkelissa tutkin, on nimeltään Wuhan-400. Station Eleven käsittelee erityisesti postapokalyptistä todellisuutta globaalin pandemian jälkeen, mutta kuvaa ajoittain myös tilannetta juuri tartuntojen alkaessa niin sanottuna nollavuotena ("Year Zero").

Tutkin teoksia nykypäivän lajiteoreettisesta näkökulmasta. Teosten viruksilla on omat lähtökohtansa eli syntytarinansa, ne leviävät salakavalasti ja toimivat tappajina, mikä herättää kauhun tunnetta teosten maailmassa. Virusten leviäminen siis edellyttää teosten hahmoilta reagointia, joka noudattaa teosten lajityypillisiä piirteitä, eli esimerkiksi tässä tapauksessa kauhua. Katastrofi- 
fiktiossa virus on vuorostaan tuhon tai mullistuksen eli katastrofin aiheuttaja. Tieteisfiktiossa viruksen syntyyn liittyvät tieteelliset perusteet ja sen olemassaoloa ja leviämistä selitetään tieteen keinoin. Sovellan siis luennassani lajiteoriaa pohtien erityisesti sitä, kuinka teokset kuvaavat tuhoisia tauteja ja taudinaiheuttajia, viruksia, ulkoisena ja vieraana uhkana sekä kauhun aiheuttajana.

\section{Virukset tieteisfiktiossa}

Lajiteknisesti on mielenkiintoista, että käsitellyt teokset edustavat yhtä aikaa kaikkia edellä mainittuja genrejä eli tieteisfiktiota, kauhua ja katastrofifiktiota. Ne ovat lajihybridejä, mikä tarkoittaa sitä, että niissä yhdistyy useamman kuin yhden lajin ominaisuuksia. ${ }^{4}$ St. John Mandel totesi Station Elevenin julkaisun jälkeen, että kyseessä ei ole tieteisfiktio, sillä teoksen tieteelliset metodit ovat todellisia ja reaalisia (ks. Charles 2014). King ja Koontz taas tunnetaan ensisijaisesti kauhukirjailijoina, mutta Tukikohdassa ja Pimeyden silmissä kauhu on pikemminkin teoksen hahmojen sekä lukijoiden kokema kauhun tuntemus, ei yliluonnollinen elementti. Koontz huomioi teoksensa jälkisanoissa, että kyseessä oli hänen varhainen yrityksensä kirjoittaa genrerajat ylittävä (cross-genre) teos, joka yhdistää toimintaa, jännitystä, romanssia ja paranormaaliutta (ED, 188). Kingin Tukikohtaa pidetään yleensä postapokalyptisena kauhuna. Toisaalta, kuten S. T. Joshi $(1990,2)$ huomauttaa, lajiteknisesti kauhu, yliluonnollinen, paranormaali ja outo ovat kirjallisuudessa usein yhteen sulautuneita.

Virusten pelko näkyy keskeisesti populaarikulttuurissamme (Thomas 2002, 1). Thomas (2002, 97-98) nostaa virukset ja bioasetuotannon yhdeksi uudeksi uhaksi ja pelotteeksi. Virusten aiheuttama näkymätön uhka onkin tieteisfiktion yksi uusista suosituista tyypeistä (Bollinger 2009, 377-78; ks. myös Dougherty 2001). Tässä artikkelissa analysoimieni teosten tarkoituksena on toimia varoittavina esimerkkeinä yhteiskunnallisesta uhasta, jonka tartuntatauti voi aiheuttaa. Samaan aikaan ne ovat populaarikirjallisuutta eli pyrkivät viihdyttämään. Tieteisfiktio, kauhu ja dystopiat ovatkin populaarikirjallisuudessa suosittuja lajeja, jotka voivat käsitellä merkittäviä yhteiskunnallisia teemoja, kuten Atwoodin teokratisen dystopian kuvaus Orjattaresi on osoittanut.

Toisaalta virukset kirjallisuudessa eivät ole olleet ainoastaan pelon ja kauhun elementtejä. Anne-Marie Thomas (2000, 143) huomauttaa, että virus ei välttämättä ole vain tuhoaja, vaan se voi olla myös evoluutiivinen vaikuttaja, muutoksen tuoja (ks. myös Bollinger 2009, 379). Koontzin Pimeyden silmissä virustartunta johtaa kehitykseen, sillä se luo ihmiselle yliluonnollisia voimia. Sekä Tukikohdassa että Station Elevenissä suuri osa ihmiskunnasta tuhoutuu, mutta tilalle nousee hitaasti uusi, virukselle immuunien ihmisten sivilisaatio. Station Eleven ei niinkään edes kuvaa sitä, mitä tapahtuu varsinaisen mullistuksen vaiheessa, vaan keskittyy siihen, kuinka yhteiskuntaa rakennetaan uudel- 
leen mullistuksen jälkeen: "20 years after the air travel" (SE, 32). Teos siis kuvaa eräänlaista pakotettua kulttuurievoluutiota, jonka virus on saanut aikaan.

Lukuisissa muissakin populaarikirjallisuuden teoksissa taudit aiheuttavat maailmanlopun esimerkiksi zombi-invaasion kautta. Jako eläviin ja epäkuolleisiin (undead) voi olla tartunnan aiheuttama. Zombismin lisäksi vampyyriyttä aiheuttaa usein tauti, niin sanottu vampyrismi, joka voi olla viruksen aikaansaama (Gordon 1988; Grixti 2014, 60). Kauhussa taas virukset ovat ajoittain ottaneet hirviön aseman. Esimerkiksi HI-viruksen aiheuttama immuunikatosairaus AIDS nousi löytymisensä jälkeen esiin uuden ajan "hirviönä" televisiossa ja elokuvassa (Guerrero 2013).

Zombi-apokalypsit tai Tukikohdan, Pimeyden silmien ja Station Elevenin kaltaiset biologista katastrofia kuvaavat kauhuteokset voidaan nähdä dystopiafiktiona, sillä ne esittävät lukijalle maailman, joka on huonompi kuin meidän asuttamamme maailma (ks. Baccolini \& Moylan 2003, 1). Dystopia-termin lähtökohtana on kauhukuva erilaisesta maailmasta, joka on termin mukaisesti "huono paikka" tai kakotopia. Reaalimaailmamme ei ainakaan toistaiseksi ole joutunut virusinvaasion tuhoamaksi eikä ihmiskulttuuri ole merkittävästi romahtanut, joten teosten maailmat ovat dystooppisia ympäröivään todellisuuteemme verrattuna. Teosten maailmat ovat fiktiivisiä, mutta toisaalta ne ovat tieteisfiktiota siinä mielessä, että vaikka maailmat ovatkin oletuksena "huonompia" kuin meidän reaalinen maailmamme, dystooppiset maailmat ovat mahdollisia ja tieteen kehittymisen myötä saavutettavissa (ks. James \& Mendlesohn 2012, 1). Tukikohdan ja Pimeyden silmien tapaan bioaseena käytetty virus voisi teoriassa levitä kaikkialle maailmaan. Station Eleveninissä kuvatun kaltainen länsimaisen kulttuurin romahdus voisi sekin periaatteessa olla mahdollinen. Romaanit ovat toisin sanoen varoituskertomuksia uhista, joita virukset voisivat pahimmillaan aiheuttaa.

\section{Virusten alkuperä}

Viruksen kaltainen ei-inhimillinen, outo ja vieras uuden ajan vihollinen sopii hyvin nykypäivän kauhufiktioon. Virukset ovat olleet aina ympärillämme, joskin olemme tunteneet ne vasta hyvin lyhyen aikaa.5 Jos kauhun aiheuttaja on vieras ja outo, ei-inhimillinen, herättää tämä lukijassa epävarmuuden tilan ja eräänlaisen "normaaliuden kriisin" (ks. Royle 2003, 1). Kauhufiktio on pelon fiktiota ja nykypäivänä juuri epävarmuus ja normaalin elämäntapamme tuhoutuminen aiheuttavat pelkoa ja kauhua. Kauhukirjailija H. P. Lovecraft $(1973,12)$ totesikin jo vuonna 1927, että tuntemattoman pelko on kauhuistamme vahvin.

Virus on ihmeellinen biologinen olio. Sillä ei ole solurakennetta tai aineenvaihduntaa ja se tarvitsee isäntäsolun lisääntyäkseen. Virus tavallaan jopa kiertää (elävän) organismin määritelmiä, sillä se on yhtä aikaa elävä ja ei-elävä (ks. Treichler 1999, 159; Thomas 2002, iii). Gerald Callahan $(2006,38)$ huomauttaa, että jopa 40-50 prosenttia ihmisen genomista koostuu virusperäisistä 


\section{Viruksen kaltainen ei-inhimillinen, outo ja vieras uuden ajan vihollinen sopii hyvin nykypäivän kauhufiktioon.}

aineksista. Ihminen elää siis jo lähtökohtaisesti pakotetussa symbioottisessa asemassa niin sanottujen vieraiden olioiden kanssa.

Viruksen pelko on samalla pelkoa tieteen tuomia mahdollisuuksia ja uhkia kohtaan. Sekä Tukikohdassa että Pimeyden silmissä virukset ovat vallanpitäjien luomuksia, bioaseita. Tukikohdassa viruksen on luonut Yhdysvaltojen hallitus: "somebody in authority got a bunch of bacteriologists, virologists, and epidemiologists together in some government installation to see how many funny bugs they could dream up. Bacteria. Viruses. Germ plasm, for all I know". (S, 121.) Pimeyden silmissä virus on niin ikään ihmiskunnan luomus. Bioaseen valjastaa vuorollaan sekä Kiina että Yhdysvallat. Yhden sen luojista, Li Chenin, loikattua myös Yhdysvallat ryhtyy välittömästi kehittelemään viruksesta omaa versiotaan: "After Li Chen defected with all the date of Wuhan-400, he was brought here. We immediately began working with him, trying to engineer an exact duplicate of the virus". (ED, 182.)

Kingin Tukikohdassa virus A-Prime, koodinimeltään "Sininen projekti", aiheuttaa superflunssaa, joka surmaa uhrinsa 99.4 prosentin varmuudella. Virus on "kavala", sillä se kykenee aina muuntautumaan, mikäli uhri onnistuu kehittämään sille vastustuskyvyn:

[T] hat meant $99.4 \%$ excess mortality, because the human body couldn't produce the antibodies necessary to stop a constantly shifting antigen virus. Every time the body did produce the right antibody, the virus simply shifted to a slightly new form. For the same reason a vaccine was going to be almost impossible to create. $(S, 19)$

Vaikka virus näissä teoksissa on tehokas tappaja ja salakavala vihollinen, sen aiheuttama tuhovoima johtuu kuitenkin inhimillisistä syistä, sillä virusta ei olisi olemassa ilman ihmisen laboratoriotyötä. Tukikohdassa myös viruksen leviäminen aiheutuu ihmisen toiminnasta, joskin tässä tapauksessa pelkuruudesta. Viruksen "karatessa" vartiosotilas Charles Campion valitsee pakenemisen perheensä luo sen sijaan, että pyrkisi eristämään tukikohdan ja sitä kautta pysäyttäisi viruksen. Campion itse on yksi viruksen uhreista, sillä hänet löydetään myöhemmin kuolleena perheensä luota Teksasista. Hänen toimiensa 
takia virus on karannut peruuttamattomasti maailmalle, siihen ei ole rokotetta ja sen aiheuttama tauti johtaa vääjäämättömästi yhteiskunnan tuhoon ja lähes koko ihmiskunnan kuolemaan.

Pimeyden silmissä ja Tukikohdassa virusten keinotekoinen alkuperä korostuu; virukset ovat biologisia aseita, jotka on suunniteltu käytettäväksi vihollisia vastaan. Kamppailu siitä, kenellä on parhaat aseet, on levinnyt myös mikroorganismien tasolle. Pimeyden silmissä todetaan, että Yhdysvalloilla on yksi biologinen asekeskus siinä missä esimerkiksi Kiinalla useita (ED, 181). Myös Station Elevenissä virus lähtee liikkeelle idästä eli Georgiasta, entisestä neuvostotasavallasta. Virus ei välttämättä ole teoksessa biologinen ase, mutta yhteiskunnallisella toiminnalla on oma roolinsa pandemian lähtökohtana, sillä Station Elevenissä sekä georgialaiset että venäläiset viranomaiset ovat salailleet kriisin vakavuutta ja sensuroineet siihen liittyvää tietoa (SE, 20). Dystooppisen tarinan logiikan mukaisesti yhteiskunta aiheuttaa vaaraa yksilöille.

Teoksissa virusten alkuperä voi olla ihmisten laboratorioista ja niiden synnyttämää pandemiaa edesauttaa viranomaisten salaileva toiminta. Jason Colavito $(2008,3)$ on huomauttanut, että kauhutarinat pyrkivät pelon kautta ylittämään ymmärryksemme mielestä, tiedosta ja tieteestä. Tarpeeksi pitkälle vietynä tiede onkin tehokas kauhun aiheuttaja. Tämän osoittaa pitkä lista "hulluista tieteentekijöistä" aina Mary Shelleyn tohtori Frankensteinista tai Robert Louis Stevensonin tohtori Jekyllistä tämän päivän geenitekniikkaan, ydinaseisiin ja tartuntatauteihin liittyviin pelkoihin. Virukset ovat meille tieteen ansiosta tuttuja, mutta dystooppiset kauhukertomukset nostavat niiden vaarallisuuden aivan uudelle tasolle. Tukikohdassa vastassa on tieteen keinoin muunneltu "superflunssa" (S, 83) ja Pimeyden silmissä parannettu versio aiemmista tehottomista viruksista, jotka tappoivat vain vanhoja, lapsia tai erittäin sairaita (SE, 59-60).

\section{Virusten leviäminen}

Vakavan tartuntataudin leviäminen aiheuttaa pelon lisäksi yhteiskunnallisia ja sosiaalisia ongelmia. Virukset ovat ei-inhimillisiä olioita, jotka "vastustavat" tiedostamattaankin ihmisten pyrkimyksiä hallita niitä. Virukset ovat lähtemätön (ulkoinen) osa ihmiskuntaa, mutta vääjäämättä myös tuhoisa elementti. Virus on erityinen monessa mielessä, sillä se kyseenalaistaa rajat itsen ja toisen välillä (ks. Thomas 2002, iii). Ihmisen tappava virus ei voi olla olemassa ilman ihmistä, mutta viruksen takia sen kantaja kuolee.

Teosten virukset ovat pelottavia, sillä ne ovat nopeita ja salakavalia. Station Elevenissä lääkärinä Toronto Generalissa toimiva Hua varoittaa teoksen alkuosan päähenkilöä, Jeevania, nopeasti leviävästä epidemiasta. Moskovasta lentäen saapunut matkustaja on tuotu hoitoon sairaalaan ja myöhemmin tulee 12 potilasta lisää. Heillä on kaikilla vaarallinen sikainfluenssan mutaatio, jota 
Hua myöhemmin vertaa SARS-epidemiaan (SE, 260). Kyseessä on kuitenkin vaarallisempi tauti, sillä viruksen leviämisnopeus on hurja.

Viruksen tarttuvuudesta kertoo se, että seuraava potilas ainoastaan työskenteli lentokentällä, jonka läpi viruksen kantajat kulkivat (SE, 16). Jeevan ymmärtää, että kyseessä on tapahtuma, joka tulee olemaan vedenjakaja koko hänen elämälleen. Viruksen aiheuttaman pandemian myötä tulee olemaan aika ennen virusta ja sen jälkeen: "Jeevan was crushed by a sudden certainty that this was it, that this illness [--] was going to be the divide between a before and an after, a line drawn though his life". (SE, 20; kursiivit alkuperäiset.)

Kiinasta maailmalle vuosina 2002-2003 epidemiana levinnyt SARS on osuva vertaus 2010-luvulla kirjoitetun Station Elevenin kontekstissa. Muissakin teoksissa pyritään tekemään viittauksia reaalimaailman epidemioihin, jotka ovat mahdollisesti lukijalle tuttuja vertailukohtia. Varhaisemmassa Pimeyden silmissä (ED, 181) virusepidemiaa verrataan Ebolaan, Afrikasta vuonna 1976 löydettyyn verenvuotokuumeeseen, joka on 1980-luvun teokselle tutumpi vertauskohta. Tukikohdassa vertailukohtana on vuorostaan HIV, jota teoksessa kutsutaan AIDS-virukseksi (S, 533).

Station Elevenissä virus jää tuntemattomaksi tappajaksi, kun taas Pimeyden silmissä siitä puhutaan avoimemmin. Viruksen kyky tappaa on ylivertainen verrattuna mihinkään tunnettuun taudinaiheuttajaan:

And Wuhan-400 has [--] important advantages over most biological agents. For one thing, you can become an infectious carrier only four hours after coming into contact with the virus. That's an incredibly short incubation period. Once infected, no one lives more than twenty-four hours. Most die in twelve. It's worse than the Ebola virus in Africa - infinitely worse. Wuhan400's kill-rate is one hundred percent. No one is supposed to survive. (ED, 181)

Kuten dystopiafiktiolle on tyypillistä, tappava virus tarjoaa myös tilaisuuden yhteiskunnalliseen kannanottoon ja kritiikkiin. Pimeyden silmissä kiinalaiset ovat testanneet virusta poliittisiin vankeihin. Yhdysvaltalaiset vuorostaan ovat valmiita kopioimaan viruksen ja käyttämään sitä yhtä lailla häikäilemättömästi. Teosten kuvaukset inhimillisestä reagoinnista virusten leviämiseen ovatkin erityisen mielenkiintoista analysoitavaa.

\section{Ihmisten reaktiot viruksiin}

Heather Urbanski on todennut teoksessaan Plagues, Apocalypses and Bug-Eyed Monsters: How Speculative Fiction Shows Us Our Nightmares (2007), että nykypäivän niin sanotussa spekulatiivisessa fiktiossa, jota kauhu, dystopia ja tieteisfiktio edustavat, huomio on usein ihmiskunnan suurimmissa peloissa. Pelkona on ihmiskunnan nykyisenkaltaisen elämän loppuminen sekä sivilisaation 
ja moraalin romahtaminen. Virukset ovat meille tuntemattomia, vaikeasti ymmärrettäviä, ja ne haluavat "syödä" tai tuhota meidät (ks. Clasen 2010, 112; Quammen 2004, 3). Virus tarvitsee ihmistä elääkseen ja lisääntyäkseen. Se on luonnon parasiitti, joka käyttää meitä ja mahdollisesti myös surmaa meidät.

Tukikohdassa ihmisen lähtökohtainen väkivaltaisuus ja pahantahtoisuus ovat edesauttaneet tappajaviruksen luomista. Huolimattomuus vapauttaa viruksen maailmalle ja inhimillinen pelkuruus estää sen eristämisen. Lopputuloksena on globaali tuho. Pimeyden silmissä virus on inhimillisen pahuuden tulos, mutta toisaalta sen kautta syntyy myös uusi paranormaali yli-ihminen, Danny. Station Elevenissä maailma tuhoutuu viruksen aiheuttaman taudin vuoksi, mutta lopussa on nähtävissä toivo uudesta alusta.

Station Elevenissä koko ihmiskunta ja sen teknologiset saavutukset romahtavat taudin takia ja tämän romahduksen pohjalta nousee uusi anarkistisempi maailmanjärjestys. Teoksessa liikutaan useilla aikatasoilla: Alussa kuvataan takaumana henkilökohtaista tragediaa, jossa näyttelijä Arthur Leander saa sydänkohtauksen kesken näytöksen ja menehtyy. Häntä jää suremaan nuori Kirsten, lapsinäyttelijä, joka on syvästi kiintynyt Arthuriin. Takauman lopussa paljastuu, että tappava virus on juuri tulossa Torontoon. Se on muuttumassa pandemiaksi ja kolme viikkoa myöhemmin suurin osa alkukohtauksessa esitellyistä henkilöistä onkin jo kuollut tautiin.

Teoksen keskeisessä ajankohdassa, kertomuksen nykyhetkessä, Kirsten on aikuinen näyttelijätär, joka vaeltaa raunioituneessa maailmassa. Viruksen aiheuttaman apokalypsin jälkeen on nähtävissä pyrkimystä vanhan maailman muistojen säilyttämiselle, sillä hylätylle lentokentälle on rakennettu epävirallinen ja vähäväkinen museo, "Museum of Civilization". Toisaalta tämä vanhan maailman tuntemus perustuu pitkälti toimimattomiksi muuttuneista kulutushyödykkeistä kuten älypuhelimista ja kannettavista tietokoneista. Teoksen lopussa yhteiskuntaa ollaan rakentamassa uudelleen ja sähkö ollaan esimerkiksi saamassa lähikaupungissa uudelleen käyttöön.

Station Elevenissä pohditaan jo maailmanlopun jälkeistä maailmaa, mutta toisaalta viruksen aiheuttama tauti on väistämättä muuttanut sitä. Voidaankin puhua pre-apokalyptisestä ajasta ennen (Time Before) vanhan maailman loppumista ja ajasta sen jälkeen (Time After) (ks. Leavenworth \& Leavenworth 2017, 22; Korpua 2017, 24). Kyseessä ei siis niinkään ole maailmanloppu konkreettisesti, sillä vanhan maailman raunioilta "luodaan" uusi maailma.

Esiin nousevat eettiset kysymykset kuten dystopioissa on usein tapana. Virus tuhoaa vanhan ja luo uuden postapokalyptisen maailman. Teoksen nykyhetkessä on päätään nostanut uskonnollinen fanatismi, jossa viruksella on oma roolinsa. Pikkukaupunkia, johon Travellin Symphony -ryhmä matkaa, pitää vallassaan "Profeetta", joka hallitsee pelolla ja väkivallalla. Uskonnollisten fanaatikkojen diktatuuri näkee virusten tuomat taudit jumalallisina. "Pahat" ovat kuolleet ja "hyvät" selvinneet. Vuosina 1918-1920 todellisessakin maailmassa raivonnutta espanjantautia Profeetta kutsuu jumalalliseksi kostoksi. 
Georgialaista virusta Profeetta palvoo myös. Hänelle virus on kostava enkeli, joka tuhosi langenneen maailman aivan kuten Raamatun Jumalan lähettämät vitsaukset konsanaan:

Have you considered the perfection of the virus? [--] And then came a virus like an avenging angel, unsurvivable, a microbe that reduced the population of the fallen world by, what? [--] I submit, my beloved people, that such a perfect agent of death could only be divine. For we have read of such a cleansing of the earth, have we not? (SE, 60)

Station Elevenin pandemian jälkeisessä maailmassa syntyy fundamentalistinen uskonnollinen yhteisö. Myös Tukikohdassa nähdään tämän kaltainen ilmiö jopa kahtena eri versiona. Toisaalta syntyy niin sanottu hyvien ihmisten yhteisö, Coloradon "Free Zone". Utopistista yhteisöä johtaa messiaaninen Äiti Abagail (Mother Abagail). Hänen vastavoimanaan toimii Randall Flagg, joka kokoaa "pahat" ihmiset omaan totalitaariseen yhteisöönsä Las Vegasiin. Flagg on yliluonnollisia voimia hallitseva julma tyranni, joka käyttää itsestään sellaisia nimikkeitä kuten "Leader of the Free People" ja "First Citizen". Flagg toteuttaa valtakunnassaan fundamentalistista lakia, jossa esimerkiksi huumausaineiden käyttö johtaa ristiinnaulitsemiseen. Toisaalta Flaggin tavoin myös Free Zonen Äiti Abagail uskoo jumalalliseen voimaan ja puhuu jumalan käden muuttamasta maailmasta: "what were miracles but the divine hand of God at work upon the earth?” (S, 335).

Station Elevenissä uskonnollinen retoriikka on niin ikään läsnä. Virus on kuoleman enkeli ja henkiin jääneet ovat saaneet armon ja heidän nimensä on kirjoitettu "elämän kirjaan" (SE, 286). Armon ovat saaneet ne, jotka eivät olleet "heikkoja" (SE, 259), lausuu teoksessa Tyler, poika, josta tulee myöhemmin Profeetta teoksen postapokalyptisessä maailmassa. Hän on mieleltään järkkynyt selviytyjä, joka lukee Raamatun Ilmestyskirjaa maanisella intohimolla ja uskoo, että pandemia tapahtui syystä.

Raamatun tematiikka nousee esiin myös Pimeyden silmissä. Teoksen päätöksessä yliluonnolliset voimat saanut Danny ja hänen äitinsä jäävät epävarmuuden tilaan, jossa heille tärkeät Raamatun Saarnaajan kirjan (3:3) sanat, joiden mukaan kaikella on määräaikansa - "aika surmata ja aika parantaa" -, eivät enää tuo lohtua:

She held Danny close, and she stared into his dark eyes, and she wasn't able to comfort herself with those words from the Bible. Danny's eyes held too much pain, too much knowledge. He was still her sweet boy - yet he was changed. She thought about the future. She wondered what lay ahead for them. (ED, 188)

Dannyn silmät ovat muuttuneet teoksen nimen mukaisesti "pimeyden silmiksi", joista viruksen aiheuttama muutos katsoo äitiä piinaavasti. Dannyn ja hänen 
äitinsä elämä on lopullisesti muuttunut, mutta ihmiskunta ei ole oppinut kokemuksesta mitään. Pimeyden silmissä armeija tulee jatkamaan eettisesti epäilyttäviä kokeitaan, sillä se on viranomaisten mukaan välttämätöntä: "Because the work has to be done. The balance of power with totalitarian states like China has to be maintained. They might pretend to close us down, but they won't'. (ED, 186.)

Tämä ihmisten jääräpäinen käyttäytyminen ja kyvyttömyys oppia mullistuksista vaikuttaa olevan teosten selkein sanoma. Myös Tukikohdassa ihmiskunta kokee suurimittaisen viruskatastrofin, muttei käytännössä opi mitään tästä kurimuksesta. Teoksen "hyvien" valtakunnan luoja Äiti Abagail kuolee uupumukseen eettisissä ponnistuksissaan ja "pahan valtiaan", Randall Flaggin, maailma tuhoutuu ydinaseen räjähdykseen (S, 511). Teoksen lopputulemana pohditaan, onko ihmiskunta oppinut virheistään. Vastaus jättää jälkeensä vain tyhjyyden tunteen:

"Do you think... do you think people ever learn anything?"

She opened her mouth to speak, hesitated, fell silent. [--]

"I don't know," she said at last. She seemed unpleased with her answer; she struggled to say something more; to illuminate her first response; and could only say it again:

I don't know. (S, 539)

\section{Lopuksi: puhuttelevia viruksia}

Kingin Tukikohta, Koontzin Pimeyden silmät ja St. John Mandelin Station Eleven ovat teoksia, jotka ovat saaneet uutta huomiota vuoden 2020 COVID-19 -pandemian levittäytyessä kaikkialle reaalimaailmaamme. Klassikkokauhukertomukset ja uudempi dystooppinen tieteisromaani ovat saaneet uutta huomiota, sillä ne kuvaavat virusten aiheuttamia epidemioita, jotka muuttavat maailmaa ja tarjoavat lukijalle pelottavan kuvan maailmasta. Romaanit ovat genrerajat ylittäviä teoksia, joiden keskiössä on virusten aiheuttama katastrofi. Tämä on aihe, joka ovat kiehtonut lukijoita jo vuosisatojen ajan, mutta joka tuntuu nykykontekstissa erityisen ajankohtaiselta.

Fiktion virukset ovat kauhun aiheuttajia, joiden avulla kauhu- ja dystopiakirjallisuus varoittavat meitä pahimmista mahdollisista skenaarioista. Ei-inhimillinen olio, virus, voidaan ottaa käyttöön bioaseena, joka luo uuden dystooppisen maailmanjärjestyksen. Virukset ovat (miltei) näkymättömiä olioita, joiden leviämisellä tai pahantahtoisella levittämisellä voi olla kauaskantoiset seuraukset. Populaarissa tieteis- ja kauhufiktiossa viruksen kautta voidaan käsitellä näitä yhteiskunnallisia ilmiöitä ja pelkoja. Kingin Tukikohdassa yhteiskunta luo bioaseiksi viruksia, jotka leviävät lopulta koko maailmaan. Koontzin Pimeyden silmissä Yhdysvaltojen armeija kopioi kiinalaisten valmistaman tappajaviruksen ja testaa sitä omiin kansalaisiinsa luoden tietämättään yliluonnollisia voimia omaavan uuden ajan ihmisen. Tai yhteiskunnan salailu mahdollistaa 
odottamattoman viruspandemian, joka tuhoaa vain muutamassa viikossa koko sivistyneen yhteiskunnan, kuten tapahtuu St. John Mandelin Station Elevenissä.

Viruksilla on kirjallisuuden kauhun aiheuttajina merkityksensä, sillä ne asettavat meidät ajattelemaan ympäröivää maailmaa. Mitä meidän tulee tehdä, ettei meille kävisi kuten Station Elevenissä, jossa vanha maailma on mennyttä? Kauhukertomukset viruksista aina Wuhanista ja Sinisestä projektista Georgialaiseen ovat meille häivähdys kauhua, joka tuntuu nyt hieman mahdollisemmalta ja kenties siksi niin puhuttelevalta.

\section{Viitteet}

1 Tämän artikkelin kirjoittamisen

hetkellä globaali pandemia pahenee hetki hetkeltä. WHO:n tuoreimmassa tilastossa (luettu 3.6.2020) tauti on levinnyt 218 maahan tai territorioon, tarttunut vahvistetusti yli 6,45 miljoonaan ihmiseen ja surmannut yli 380000 ihmistä. Tilastot päivittyvät koko ajan ja todelliset luvut tarkentuvat vasta pandemian jälkeen.

2 Tämän artikkelin keskeisin innoittaja on ollut ajankohtainen COVID-19-pandemia, vaikka artikkeli ei tutkikaan reaalimaailman pandemioita tai edes juuri viittaa niihin muutamaa pientä poikkeusta lukuun ottamatta.

3 King ja Koontz ovat aikamme myydyimpiä kirjailijoita, todellisia kauhun supermenestyjiä: Kingin teoksia on myyty yli 350 miljoonaa kappaletta (Morgan 2006), ja Koontz on kenties vieläkin menestyneempi yli 400 miljoonalla myydyllä teoksellaan (Titus 2011). St. John Mandelin Station Eleven on bestseller, joka on voittanut British Science Fiction Associationin Arthur C.
Clarke-palkinnon. HBO adaptoi teoksen 10-osaiseksi televisiosarjaksi vuonna 2020. Kingin Tukikohdasta on puolestaan tulossa CBS: $n$ televisiosarja. Teokset ovat siis suosittuja ja yleisön silmissä kiinnostavia. Tämä ei kuitenkaan ole uusi ilmiö, joka aiheutuisi pelkästään virusepidemiasta, vaan uudemman dystopiafiktion määritteleviä piirteitä on sen viihdearvo (ks. Baxter, Grubisic, \& Lee 2014, 7-10; Morrissey 2013, 189). Pelko, jopa globaalin pandemian pelko, voi olla viihdyttävää.

4 David Duff (2000, xiv) toteaa lajihybridin olevan teksti, jossa yhdistyy elementtejä kahdesta tai useammasta genrestä. Tutkimuksessa puhutaan nykyään usein lajin "hämärtymisestä" (blurring) ennemmin kuin hybrideistä, vaikka konsepti onkin pitkälti sama (ks. Allen 2013).

5 Virukset on entiteettinä tunnettu vasta vuodesta 1892 lähtien Dimitri Ivanovskin tutkimusten myötä (ks. esim. van Regenmortel 2010, 20).

\section{Aineisto}

King, Stephen 1978. The Stand: A Novel [= S]. New York: Doubleday \& Company. Koontz, Dean R. 1996 (1981). The Eyes of Darkness [= ED]. Revised version. New York: Berkley Books. St. John Mandel, Emily 2014. Station Eleven: A Novel [= SE]. New York: Alfred A. Knopf. 


\section{Kirjallisuus}

Aguirre, Manuel 1990. The Closed Space: Horror Literature and Western Symbolism. Manchester: Manchester University Press.

Allen, Martina 2013. Against Hybridity in Cenre Studies: Blending as an Alternative Approach to Ceneric Experimentation. Trespassing Journal, 2. http://trespassingjournal.org/Issue2/ TP]_I2_Allen_Article.pdf (27.4.2020).

Amazon 2017. https://www.amazon.com/article/this-year-in-books (27.4.2020).

Baccolini, Raffaella \& Tom Moylan 2003. Introduction: Dystopia and Histories. Teoksessa Dark Horizons: Science Fiction and the Dystopian Imagination. Eds Raffaella Baccolini \& Tom Moylan. New York \& London: Routledge, 1-12.

Baxter, Gisèle M., Brett Josef Crubisic \& Tara Lee 2014. Introduction. Teoksessa Blast, Corrupt, Dismantle, Erase: Contemporary North American Dystopian Literature. Eds Gisèle M. Baxter, Brett Josef Crubisic \& Tara Lee. Waterloo: Wilfrid Laurier University Press, 7-22.

Blondheim, S. H. 1955. The First Recorded Epidemic of Pneumonic Plague: The Bible, I Sam. VI. Bulletin of the History of Medicine 29(4), 337-45.

Bollinger, Laurel 2009. Containing Multitudes: Revisiting the Infection Metaphor in Science Fiction. Extrapolation 50(3), 377-99.

Callahan, Gerald N. 2006. Infection: The Hidden Universe. New York: St. Martin's.

Clasen, Mathias 2010. The Horror! The Horror! The Evolutionary Review 1(1), 112-19.

Charles, Ron 2014. Sorry, Emily St. John Mandel: Resistance is Futile. Washington Post, 15.10.2014. https://www.washingtonpost.com/news/arts-and-entertainment/wp/2014/10/15/sorry-emily-st-john-mandel-resistance-is-futile/?arc404=true (27.4.2020).

Colavito, Jason 2008. Knowing Fear: Science, Knowledge and the Development of the Horror Cenre. Jefferson, NC: McFarland \& Company.

Dougherty, Stephen 2001. The Biopolitics of the Killer Virus Novel. Cultural Critique 48, 1-29. https:// www.jstor.org/stable/1354395.

Duff, David 2000. Key Concepts. Teoksessa Modern Cenre Theory. Ed. David Duff. Harlow: Longman, $\mathrm{x}-\mathrm{xvi}$.

Flood, Alison 2020. Publishers Report Sales Boom in Novels about Fictional Epidemics. The Guardian 5.3.2020. https://www.theguardian.com/books/2020/mar/05/publishers-report-salesboom-in-novels-about-fictional-epidemics-camus-the-plague-dean-koontz (27.4.2020).

Freytas-Tamura, Kimiko de 2017. George Orwell's "1984" Is Suddenly a Best-Seller. The New York Times 25.1.2018. https://www.nytimes.com/2017/01/25/books/1984-george-orwell-donaldtrump.html (27.4.2020).

Comel, Elena 2000. The Plague of Utopias: Pestilence and the Apocalyptic Body. Twentieth Century Literature 46(4), 405-33. DOI 10.2307/827840.

Cordon, Joan 1988. Rehabilitating Revenants, or Sympathetic Vampires in Recent Fiction. Extrapolation 29(3), 227-34

Crixti, Joseph 2014 (1989). Terrors of Uncertainty: The Cultural Contexts of Horror Fiction. New York: Routledge Revivals.

Guerrero, Edward 1990. AIDS as Monster in Science Fiction and Horror Cinema. Journal of Popular Film and Television 18(3), 86-93. DOI: 10.1080/01956051.1990.10662021.

Harrison, R. K. 1953. Disease, Bible and Spade. The Biblical Archaeologist 16(4), 88-92. DOI: $10.2307 / 3209144$

Isomaa, Saija \& Toni Lahtinen 2017. Kotimaisen nykydystopian monet muodot. Teoksessa Pakkovaltiosta ekodystopiaan: Kotimainen nykydystopia. Toim. Saija Isomaa \& Toni Lahtinen. Helsinki: Joutsen / Svanen, erikoisjulkaisuja 2, 7-16. 
Isomaa, Saija, Jyrki Korpua \& Jouni Teittinen 2020. Navigating the Many Forms of Dystopian Fiction. Teoksessa New Perspectives on Dystopian Fiction in Literature and Other Media. Eds Saija Isomaa, Jyrki Korpua \& Jouni Teittinen. Newcastle upon Tyne: Cambridge Scholars Publishers, ix-xxxii.

James, Edward \& Farah Mendlesohn 2012. Introduction. Teoksessa Cambridge Companion to Fantasy Literature. Eds Edward James \& Farah Mendlesohn. Cambridge: Cambridge University Press, $1-4$.

Joshi, S. T. 1990. The Weird Tale. Holicong, PA: Wildside Press.

Kelly, Hillary 2020. The Disaster Artist Emily St. John Mandel's Station Eleven Is Speaking to our Pandemic-frenzied Moment: Her New Book Is Even Bleaker. https://www.vulture.com/2020/03/ glass-house-station-eleven-emily-st-john-mandel.html (27.4.2020).

Korpua, Jyrki 2017. Mitä otat mukaasi tästä maailmasta? Postapokalyptisen nuorten fiktion lainalaisuudet K. K. Alongin romaanissa Kevätuhrit. Avain 14(3), 22-37. DOI: 10.30665/av.66379.

Leavenworth, Maria Lindgren \& Van Leavenworth 2017. Fragmented Fiction: Storyworld Construction and the Quest for Meaning in Justin Cronin's The Passage. Fafnir-Nordic Journal of Science Fiction and Fantasy Research 4(2), 22-33. http://journal.finfar.org/articles/fragmented-fiction/.

Lovecraft, H. P. 1973 (1927). Supernatural Horror in Literature. New York: Dover Publication.

Martin, Henry 2020. Panic-reading! Dean Koontz's 1981 Thriller about a Deadly Virus from Wuhan Tops Bestseller Lists 39 Years on as Fans say It 'Predicted the Coronavirus Outbreak'. Daily Mail 4.3.2020. https://www.dailymail.co.uk/news/article-8075853/Dean-Koontzs-1981-thrillerdeadly-virus-Wuhan-bestseller.html (27.4.2020).

Morgan, Robert 2006. Newsnight: Stephen King. BBC News, 22.11.2006. http://news.bbc.co.uk/2/hi/ programmes/newsnight/6174256.stm (27.4.2020).

Morrissey, Thomas ]. 2013. Parables for the Postmodern, Post-9/11, and Posthuman World. Carrie Ryan's Forest of Hands and Teeth Books, M. T. Anderson's Feed, and Mary E. Pearson's The Adoration of Jenna Fox. Teoksessa Contemporary Dystopian Fiction for Young Adults: Brave New Teenagers. Eds Balaka Basu, Katherine R. Broad \& Carrie Hintz. New York: Routledge, 189-202.

Quammen, David 2004. Monster of Cod. New York: W. W. Norton.

Royle, Nicholas 2003. The Uncanny: An Introduction. Manchester: Manchester University Press.

Thomas, Anne-Marie 2000. To Devour and Transform: Viral Metaphors in Science Fiction by Women. Extrapolation 41(1), 143-60.

Thomas, Anne-Marie 2002. It Came from Outer Space: The Virus, Cultural Anxiety, and Speculative Fiction. Väitöskirja. Baton Rouge: Louisiana State University and Agricultural and Mechanical College. https://digitalcommons.Isu.edu/cgi/viewcontent.cgi?referer=https://scholar.google. com/\&httpsredir=1\&article=5084\&context=gradschool_dissertations (27.4.2020).

Titus, Tom 2011. Slaughter with a Smile. Los Angeles Times. Daily Pilot. https://www.latimes.com/ socal/daily-pilot/entertainment/tn-dpt-xpm-2011-01-07-tn-dpt-0108-titus-20110107-story. html (27.4.2020).

Treichler, Paula 1999. How to Have a Theory in an Epidemic: Cultural Chronicles of AIDS. Durham, NC: Duke University Press.

Urbanski, Heather 2007. Plagues, Apocalypses and Bug-Eyed Monsters: How Speculative Fiction Shows Us Our Nightmares. Jefferson, NC: McFarland \& Company.

WHO, World Health Organization 2020. Coronavirus Disease (COVID-19) Pandemic. https://www. who.int/emergencies/diseases/novel-coronavirus-2019 (27.4.2020).

van Regenmortel, Marc H. V. 2010: Nature of Viruses. Teoksessa Desk Encyclopedia ofCeneral Virology. Eds Brian W. J. Mahy \& Marc H. V. van Regenmortel. Oxford: Elsevier, 19-22. 